\title{
EFFECT OF MELATONIN ON DOPAMINE SECRETION IN THE HYPOTHALAMUS OF MATURE FEMALE COMMON CARP, CYPRINUS CARPIO L.
}

\author{
Włodzimierz POPEK ${ }^{1}$, Ewa $L U S Z C Z E K-T R O J N A R^{1 *}$, Ewa DRĄG-KOZAK ${ }^{1}$, \\ Janusz RZACA ${ }^{2}$, Piotr EPLER ${ }^{1}$ \\ ${ }^{1}$ Division of Ichthyobiology and Fisheries, \\ 2 Division of Animal Physiology; University of Agriculture in Kraków, Poland
}

Popek W., Łuszczek-Trojnar E., Drag-Kozak E., Rząsa J., Epler P. 2006. Effect of melatonin on dopamine secretion in the hypothalamus of mature female common carp, Cyprinus carpio L. Acta Ichthyol. Piscat. 36 (2): 134-141.

\begin{abstract}
Background. The work was the continuation of previous study, which indicated that melatonin influences the inhibition of hypothalamic dopamine secretion in vitro. In the presently reported study, the influence of melatonin injection into the third cerebral ventricle on the release of dopamine was tested. The aim of this study was to investigate if and how melatonin affects dopamine secretion in the hypothalamus of mature female carp.

Materials and Methods. The concentration of dopamine in hypothalamic tissue was determined radioenzymatically. The experimental groups were fish deprived of melatonin by pinealectomy, fish that received intraventricular injections of melatonin, fish that received intraventricular injections of physiological saline, and intact fish (control treatment). The study was carried out in the summer during spawning and in the winter when fish gonads were regressed.

Results. Melatonin injection resulted in an increase in dopamine concentration in the hypothalamus, which indicates that melatonin influenced aminergic nuclei inhibiting secretion of dopamine. Dopamine probably remained unreleased in the hypothalamic tissue, whereas in pinealectomized fish the lack of melatonin influenced continuous dopamine secretion, what was shown as the low dopamine level in the hypothalamus. The results confirmed the previous study effect of melatonin in mature female carp, and point to an inhibitory effect of intraventricularly injected melatonin on the release of dopamine from the hypothalamus. This effect occurred only in the summer experiment, indicating a seasonal impact of melatonin on the dopaminergic system.

Conclusion. By inhibiting the release of hypothalamic dopamine, which blocks gonadotropin secretion, melatonin has a potential stimulatory effect on the release of $\mathrm{LH}$ and in this way may be involved in control of reproduction in carp.
\end{abstract}

Keywords: fish, carp, Cyprinus carpio, dopamine, hormonal control of reproduction, melatonin

\section{INTRODUCTION}

In fish, just as in higher vertebrates, melatonin has a chronobiological function. In addition, this hormone may affect pituitary activity (Fenwick 1970a) and regulate gonadal function (Peter 1968, 1970, Fenwick 1970b, Urasaki 1972, de Vlaming 1974, Popek et al. 1991, 2002, Bayarri et al. 2004).

Studies on the effect of melatonin on reproductive processes in fish, most often, point to its stimulatory or inhibitory effect depending on the species, season of the year, time of the day, and degree of sexual maturity, but fail to show how and where melatonin affects the reproductive system. Ghosh and Nath (2005) showed that melatonin is effective in inhibiting ovarian vitellogenesis, plasma GtH
II levels, and gonadosomatic index (GSI) in a catfish (Clarias batrachus). So melatonin may control the reproduction by blocking maturation gonadotropin (LH) release from the pituitary. Opposite effect showed Breton et al. (1993) who observed increase of LH level in blood, after melatonin injection conducted during the night (dark phase) to mature female carp. During the long day the pineal gland and melatonin stimulate the final stages of sexual maturation by synchronizing full oocyte maturity with the optimal spawning period and stimulate vitellogenesis in the post-spawning period in carp (Popek et al. 1991). It was also reported that melatonin modulates the hypothalamic dopaminergic system rather (Popek 1991, Popek et al. 1994) than directly affecting gonads (Popek et 
al. 1996) or the pituitary gland (Popek et al. 1994, 2000), although in other fish species direct melatonin action on the pituitary was observed (Khan and Thomas 1996, Gaildrat and Falcón 2000). It seems that melatonin can affect reproductive functions most likely by a dopaminergic pathway, which is supported by Zisapel and Laudon (1983) and Zisapel et al. (1985) who proved that melatonin is able to inhibit the hypothalamic secretion of dopamine in rats. Dopamine is one of catecholamines produced by hypothalamic aminergic nuclei NRL (nucleus recessus lateralis) and NRP (nucleus recessus posterioris). Dopamine is the most dominant gonadotropin-releasing inhibiting factor (GRIF) (Chang and Peter 1983). The inhibiting effect of dopamine was also proved on LHRH synthesis and secretion (Yu and Peter 1990).

Previous studies on the effect of melatonin on the activity of hypothalamic aminergic nuclei in mature female carp, using the Falck-Hillarp histochemical fluorescence technique, also confirmed the ability of melatonin to inhibit the secretion of catecholamines produced by the hypothalamus (Popek and Epler 1999). Given that dopamine accounts for $70 \%$ of hypothalamic catecholamines (le Bras 1979), these results support the earlier hypotheses concerning the inhibitory role of melatonin on the dopaminergic system in the carp.

The results of experiments in vitro, where carp females hypothalami were perifused with, or without melatonin addition, also indicated that melatonin inhibited hypothalamic dopamine release (Popek et al. 2005).

The aim of the present study was to investigate the effect of melatonin on dopamine release in the hypothalamus of mature female carp. Experiments were conducted in summer during the spawning period of carp and in winter when fish gonads were regressed, to indicate possible seasonal effects.

\section{MATERIALS AND METHODS}

Eighty 5-year old mature females of common carp, Cyprinus carpio L., from an Experimental Fish Farm of the Division of Ichthyobiology and Fisheries, Agricultural University in Kraków were used in the experiment.

After harvesting from breeding ponds, fish were moved to a facility with concrete tanks, each having a volume of $2 \mathrm{~m}^{3}$. Stock density was of $14 \mathrm{~kg} \cdot \mathrm{m}^{-3}$. The intensity of artificial lighting, placed above each tank, measured over the water surface, was at least $2000 \mathrm{~lx}$. The time the light was on corresponded with the current environmental conditions. During spawning in the summer (June), the ratio of light : dark (L:D) was $16: 8$ and the light was turned on at $0400 \mathrm{~h}$. In the winter (December) an $8: 16$ light regime $(\mathrm{L}: \mathrm{D})$ was used and the light was turned on at $0800 \mathrm{~h}$. Water flow in the tanks was adjusted to four complete tank changes each day. Water in the tanks was artificially aerated and the level of dissolved oxygen was at least $6 \mathrm{mg} \mathrm{O}_{2} \cdot \mathrm{L}^{-1}$. The water temperature in tanks also corresponded with the current environmental conditions. The water temperature in tanks was adjusted to $18^{\circ} \mathrm{C}$ (the average water temperature in ponds in June). In the win- ter, the average water temperature as in ponds as in tanks was $7^{\circ} \mathrm{C}$. Carp were acclimated to the artificial conditions for seven days prior to the commencement of the experiments.

Prior to all manipulations, fish harvested from the tanks were anaesthetized with $1 \%$ ethylene glycol monophenyl ether (Merck).

Summer period (water temperature $22^{\circ} \mathrm{C}, \mathrm{L}: \mathrm{D}=16: 8$ ). Forty carp weighing an average of $2.8 \mathrm{~kg}$ were divided into 4 groups (each having 10 fish):

Four days before the experiment began, in Group 1, all the fish were pinealectomized (Px), as described by Popek et al. (1994), in groups 2 (ivM) and 3 (ivC), injection needle conduits leading to the third cerebral ventricle were implanted as described by Popek (1991).

After that period, midway through the dark phase ( $2400 \mathrm{~h}$; midnight), fish from group 2 received melatonin microinjections $\left(1 \mu \mathrm{g} \mathrm{MT} \cdot \mu \mathrm{L}^{-1} \mathrm{NaCl} 0.6 \%\right.$ per $1 \mathrm{~kg}$ body weight) into the third cerebral ventricle. Melatonin was predissolved in $5 \mu \mathrm{L}$ of $96 \%$ ethanol and then in a solution of physiological saline. Experimental melatonin treatment occurred during the night when melatonin levels would have been high in intact fish, in order to minimize potential circadian variation in melatonin receptor levels (Zisapel et al. 1998, Brooks and Cassone 1992, MassonPévet et al. 2000, Schuster et al. 2001).

Fish from group 3 received intraventricular injections of physiological solution supplemented with $5 \mu \mathrm{L}$ of $96 \%$ ethanol.

Fish from group 4 remained intact (C).

Fifteen min after intraventricular injection, all the fish were killed and decapitated as soon as possible (about $30 \mathrm{~s})$. The collected hypothalami were stored at $-60^{\circ} \mathrm{C}$ until the level of dopamine was determined.

Winter period (water temperature $5^{\circ} \mathrm{C}, \mathrm{L}: \mathrm{D}=8: 16$ ). Forty carp weighing an average of $2.6 \mathrm{~kg}$ were divided into 4 groups (each having 10 fish). Further treatment and injection type and method were the same as in the summer period.

The collected hypothalami were analysed radioenzymatically to determine the level of dopamine using commercial kit (Immunotech, a Coulter Company) (Johnson et al. 1980), commonly used in fish studies (le Bras 1984, Senthilkumaran and Joy 1995).

The results were analyzed using one-way analysis of variance. Student's t-test was used to determine statistical differences between the groups.

The experimental protocol was approved by the Local Ethical Committee for Experiments on Animals, Jagiellonian University in Kraków.

\section{RESULTS}

Summer period. In the summer, the level of dopamine (DA) in the hypothalamus of pinealectomized fish (group 1 , Px) was the lowest, averaging $1.44 \pm 0.12 \mu \mathrm{g} \cdot \mathrm{g}^{-1}$ tissue. In the hypothalamus of females that received intraventricular injection of melatonin (group 2, ivMT), the 
level of dopamine was the highest, averaging $2.23 \pm 0.21$ $\mu \mathrm{g} \cdot \mathrm{g}^{-1}$ tissue. In females microinjected with a physiological saline solution (group 3, ivC), the hypothalamic level of dopamine averaged $2.09 \pm 0.19 \mu \mathrm{g} \cdot \mathrm{g}^{-1}$ tissue. In the hypothalamus of control females (group 4, C), the average level of dopamine was $1.75 \pm 0.15 \mu \mathrm{g} \cdot \mathrm{g}^{-1}$ tissue.

Statistical analysis showed that the difference between DA concentrations in groups 1 and 2 was statistically significant $(P<0.01)$.

Fig. 1 shows the pattern of changes in the hypothalamic dopamine level in mature female carp in particular groups during the summer. nificantly $(P<0.01)$ lower in the winter than the level of dopamine in corresponding groups during the summer.

\section{DISCUSSION}

In the present study, hypothalami taken from fish, after the injection, were analysed radioenzymatically, which allowed the actual dopamine concentration to be determined. During the summer, the highest level of dopamine $\left(2.23 \mu \mathrm{g} \cdot \mathrm{g}^{-1}\right.$ tissue, on average) was observed in the group of females, which received intraventricular melatonin injections (group 2). Dopamine concentration was significantly $(P<0.01)$ higher than that in the group of

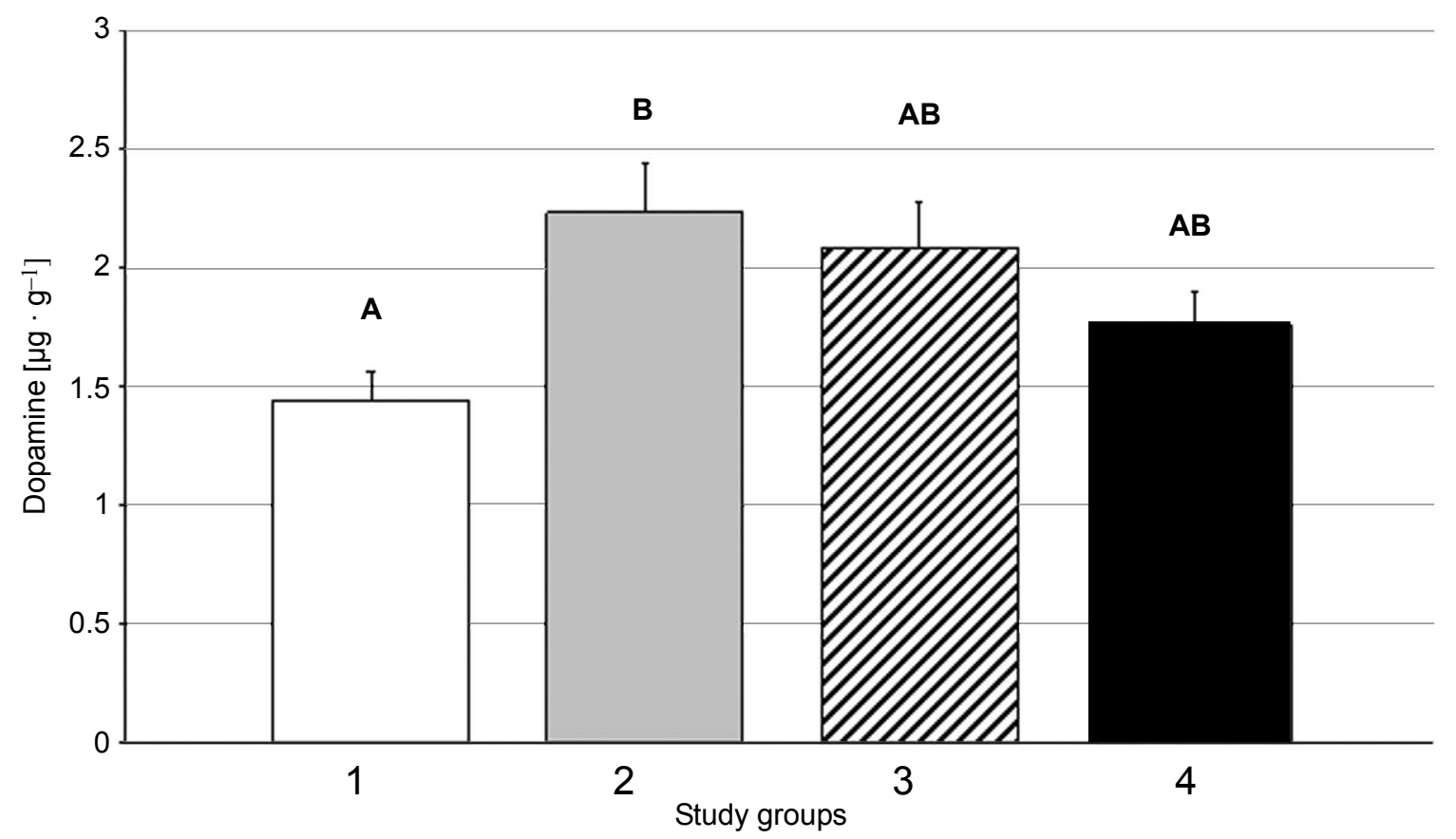

Fig. 1. Mean $( \pm s)$ dopamine concentrations in the hypothalamus of female carp during the summer in pinealectomized fish (group 1; Px), intraventriculary melatonin injected fish (group 2; ivMT), intraventriculary $\mathrm{NaCl}$ injected fish (group 3; ivC) and intact fish (group 4; C); different letters indicate significant difference $(P<0.01)$

Winter period. The winter experiment showed that the level of dopamine in the hypothalamus of pinealectomized fish (group 1, Px) was the lowest, averaging 1.07 $\pm 0.12 \mu \mathrm{g} \cdot \mathrm{g}^{-1}$ tissue. In the hypothalamus of females, which received intraventricular melatonin infusions (group 2, ivMT) the level of dopamine was the highest, averaging $1.44 \pm 0.17 \mu \mathrm{g} \cdot \mathrm{g}^{-1}$ tissue. In females microinjected with a physiological saline solution (group 3,ivC) the average level of dopamine in the hypothalamus was $1.08 \pm 0.08 \mu \mathrm{g} \cdot \mathrm{g}^{-1}$ tissue. In the hypothalamus of control females (group 4, C), the average dopamine level was $1.15 \pm 0.09 \mu \mathrm{g} \cdot \mathrm{g}^{-1}$ tissue. Statistical analysis did not show any significant $(P<0.05)$ differences between the groups.

Fig. 2 shows changes in the hypothalamic level of dopamine in mature female carp in particular groups during the winter.

Statistical analysis revealed that the level of dopamine in the hypothalamus of fish in particular groups was sig- pinealectomized fish $\left(1.44 \mu \mathrm{g} \cdot \mathrm{g}^{-1}\right.$ tissue, on average; group 1) (Fig. 1). Low concentration of dopamine, found in the hypothalami of fish after pinealectomy treatment indicates the release of this hormone from aminergic nuclei while a lack of melatonin. Endogenous melatonin present in fish of control groups $(\mathrm{NaCl}$-injected - group 3 and intact-group 4) insignificantly inhibited dopamine secretion from aminergic nuclei. Stronger inhibiting effect was observed after intraventricular injection of exogenous melatonin in fish of group 2. The same results were observed in in vitro experiments (Popek et al. 2005), where hypothalami were perifused in the medium containing melatonin or pineal glands were implanted into hypothalamic tissue. But then, dopamine concentration was analyzed in samples of the effluent perifusate, not in the hypothalamic tissue. The highest dopamine levels were secreted by control hypothalami perifused without melatonin addition, and the lowest dopamine levels were found in group with hypothalami perifused in the medium con- 


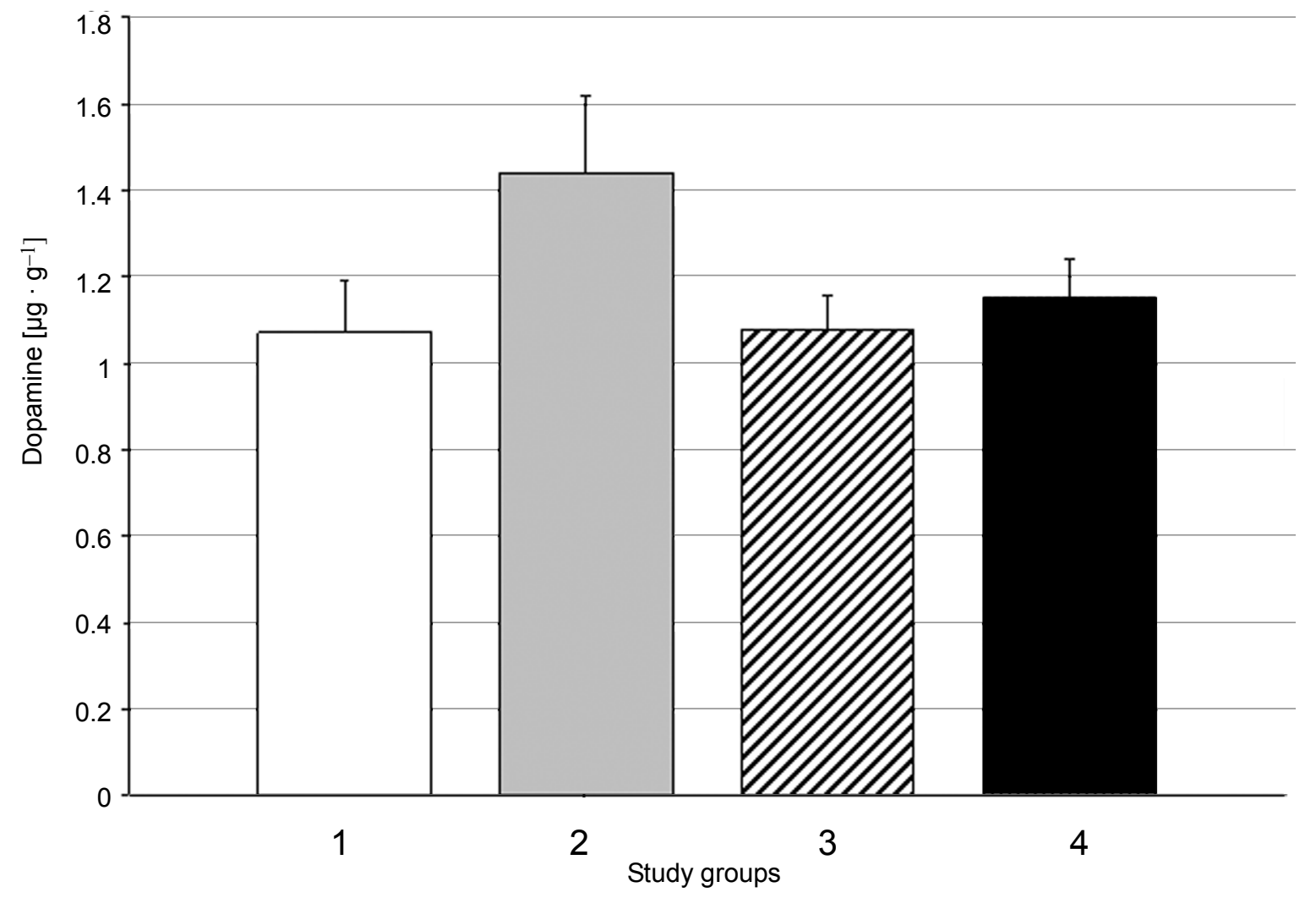

Fig. 2. Mean $( \pm s)$ dopamine concentrations in the hypothalamus of female carp during the winter in pinealectomized fish (group 1; Px), intraventriculary melatonin injected fish (group 2; ivMT), intraventriculary $\mathrm{NaCl}$ injected fish (group 3; ivC) and intact fish (group $4 ; \mathrm{C}$ )

taining exogenous melatonin, whereas in the present study the lowest concentration of dopamine was determined in the hypothalamic tissue of pinealectomized fish and the highest dopamine level was determined in the hypothalamic tissue after exogenous melatonin injection. In the present work no significant differences were determined between control group (intact or ivC) and the group of fish, which received the intraventricular melatonin injection (group 2). It should be noted that the dose of melatonin used in the experiment was physiological not pharmacological. On the other hand, the pinealectomy treatment totally eliminates blood level of melatonin in fish (Popek et al 1997). This may be the reason why significant differences were observed only in comparison to pinealectomized fish. Maybe it would be possible to observe higher or lower dopamine levels in the hypothalamus in case of use another dose of melatonin. But the aim of the study was to examine if melatonin is able to influence dopamine secretion. These results support our earlier hypothesis that melatonin, by leading to increased dopamine concentration in aminergic nuclei of the hypothalamus, may inhibit the release of hypothalamic dopamine during the summer. These data confirm the results obtained by Hernández-Rauda et al. (2000), who was studying the influence of melatonin on dopamine and 3,4-dihydroxyphenylacetic acid (DOPAC) metabolism in the hypothalamus and the pituitary of rainbow trout. The increase in circulating melatonin was accompanied by a reduction in the amount of DOPAC in the hypothalamus and the pituitary.

During the winter, dopamine concentration in hypothalamic aminergic nuclei of female carp was lower than that in the summer and ranged from 1.07 to $1.44 \mu \mathrm{g} \cdot \mathrm{g}^{-1}$ tissue (Fig. 2). Analysis of these results shows that the dopamine level in the hypothalamus of fish with regressed gonads in the winter is by 30 percentage points lower than that observed during the summer $(P<0.01)$. It is also evident (as during the summer period) that in the winter melatonin exerted a certain effect on the hypothalamic concentration of dopamine, but differences between particular groups of fish were not significant.

It should also be added that the findings of our previous research (Popek and Epler 1999, Popek et al. 2005) and our present findings are convergent, showing a similar response of the aminergic system to melatonin. What is also evident is the seasonal activity of the hypothalamicpineal system, which reflects the sexual cycle of the whole carp family. The physiological activity of fish increases in the summer, when gonads become able to produce mature gametes, and reaches a peak during the spawning period. Spawning (second half of spring) is followed by the regeneration of gonads and its end in the autumn coincides with winter regression that lasts for several months. Melatonin, by acting as hormonal hands of the biological clock (pin- 
eal gland) synchronizes the fish with the changing environment. This seasonal (summer-winter) influence of melatonin on the hypothalamic dopamine secretion of the carp serves as a good example.

Discussing the role of melatonin in carp reproduction it is worth to mention that melatonin also stimulates hypothalamic noradrenaline secretion in spawning time, what was showed in experiments in vivo and in vitro in maturing carp female (Drag-Kozak et al. 2004). Melatonin affects not only the level of catecholamines in the carp hypothalamus by stimulating or inhibiting their release during the summer, but can also take part in the indirect stimulation of LH release by stimulating and inhibiting the activity of the aminergic system. This hypothesis is possible because in the family Cyprinidae noradrenaline stimulates GnRH release and LH secretion in mature fish female (Chang et al. 1991, Peter et al. 1991) and dopamine acts as a hypothalamic factor that inhibits LH secretion. Dopamine is the most dominant inhibitory mechanism that inhibits basal or GnRH-induced LH release in several species (Chang and Peter 1983, Chang et al. 1984, Senthilkumaran and Joy 1996). Therefore the stimulation of noradrenaline and inhibition of dopamine activity may lead to increased secretion of LH, which during the spawning period most often leads to oocyte ovulation and spawning of fish. Enhancing spawning in fish by removal of dopaminergic inhibition became a popular treatment $(\mathrm{Ku}-$ makura et al. 2003, Aizen et al. 2005). The use of GnRH and its superactive analogues in combination with dopamine receptor antagonists (pimozide, domperidone, or metaclopramide) has become the basis of a simple and reliable method of influenced breeding in teleosts (Peter et al. 1991, Yaron 1995). This provides very good results, but can evoke side effects as mortality (Kucharczyk et al. 1999). So the replacement of synthetic drugs by natural melatonin seems to be serious alternative for fisheries. Further research is required to examine the dose and time as well the way of administration dependence of melatonin treatment, on LH secretion, ovulation and spawning efficiency in carp.

\section{ACKNOWLEDGMENTS}

This work was supported financially by the State Committee for Scientific Research (KBN), Poland (grants Nos. 5 P06D 019 and 6 P06D 03921).

\section{REFERENCES}

Aizen J., Meiri J., Tzchori I., Levavi-Sivan B., Rosenfeld H. 2005. Enhancing spawning in the grey mullet (Mugil cephalus) by removal of dopaminergic inhibition. General and Comparative Endocrinology 142: 212-221.

Bayarri M.J., Rodriguez L., Zanuy S., Madrid J.A., Sanchez-Vazquez F.J., Kagawa H., Okuzawa K., Carrillo M. 2004. Effect of photoperiod manipulation on the daily rhythms of melatonin and reproductive hormones in caged European sea bass (Dicentrarchus labrax). General and Comparative Endocrinology 136: 72-81. le Bras Y.M. 1979. Circadian rhythm in brain catecholamine concentrations in the teleost Anguilla anguilla L. Comparative Biochemistry and Physiology C 62: 115-117.

le Bras Y.M. 1984. Circadian variations of catecholamine levels in brain, heart, and plasma in the eel, Anguilla anguilla L., at three different times of year. General and Comparative Endocrinology 55: 472-479.

Breton B., Mikołajczyk T., Popek W. 1993. The neuroendocrine control of the gonadotropin $\left(\mathrm{GtH}_{2}\right)$ secretion in teleost fish. Pp. 199-215. In: Lahlon B., Vitiello P. (eds.) Aquaculture: Fundamental and applied research. Coastal and Estuarine Studies Series 43. American Geophysical Union, Washington, DC.

Brooks D.S., Cassone V.M. 1992. Daily and circadian regulation of $2-\left[{ }^{125} \mathrm{I}\right]$ iodomelatonin binding in the chick brain. Endocrinology 131: 1297-1304.

Chang J.P., MacKenzie D.S., Gould D.R., Peter R.E. 1984. Effects of dopamine and norepinephrine on in vitro spontaneous and gonadotropin-releasing hormone-induced gonadotropin release by dispersed cells or fragments of the goldfish pituitary. Life Science 35: 2027-2033.

Chang J.P., Peter R.E. 1983. Effects of dopamine on gonadotropin release in female goldfish, Carassius auratus. Neuroendocrinology 36: 351-357.

Chang J.P., Van Goor F., Acharya S. 1991. Influences of norepinephrine and adrenergic agonists and antagonists on gonadotropin secretion from dispersed pituitary cells of goldfish, Carassius auratus. Neuroendocrinology 54: 202-210.

Drąg-Kozak E., Popek W., Łuszczek-Trojnar E., Fortuna-Wrońska D., Epler P. 2004. The influence of melatonin on noradrenaline and adrenaline release in maturing carp females (Cyprinus carpio L.). Naukovij vìsnik L'vìvskoï nacìonal'noï akademiï veterinarnoï medicini ìmenì S. Z. Gžic'kogo = Scientific Messenger of Lviv National Academy of Veterinary Medicine named after S.Z. Gzhytskyj 6 (2): 64-70.

Fenwick J.C. 1970a. The pineal organ: Photoperiod and reproductive cycles in the goldfish, Carassius auratus L. Journal of Endocrinology 46: 101-111.

Fenwick J.C. 1970b. Demonstration and effect of melatonin in fish. General and Comparative Endocrinology 14: 86-97.

Gaildrat P., Falcón J. 2000. Melatonin receptors in the pituitary of a teleost fish: mRNA expression, 2[125I]iodomelatonin binding and cyclic AMP response. Neuroendocrinology 72: 57-66.

Ghosh J., Nath P. 2005. Seasonal effects of melatonin on ovary and plasma gonadotropin and vitellogenin levels in intact and pinealectomized catfish, Clarias batrachus (Linn). Indian Journal of Experimental Biology 43: 224-232.

Hernández-Rauda R., Miguez J.M., Ruibal C., Aldegunde M. 2000. Effects of melatonin on dopamine metabolism in the hypothalamus and the pituitary of the rainbow trout, Oncorhynchus mykiss. Journal of Experimental Zoology 287: 440-444. 
Johnson G.A., Kupiecki R.M., Baker C.A. 1980 Single isotope derivative (radioenzymatic) method in measurement of catecholamines. Metabolism 29 (Suppl. 1): 1106-1113.

Khan I.A., Thomas P. 1996. Melatonin influences gonadotropin II secretion in the Atlantic croaker (Micropogonias undulatus). General and Comparative Endocrinology 104: 231-242.

Kucharczyk D., Kujawa R., Mamcarz A., Wyszomirska E., Ulikowski D. 1999. Artificial spawning of ide (Leuciscus idus) under controlled conditions. Electronic Journal of Polish Agricultural Universities, Fisheries 2 (2): http://www.ejpau.media.pl/volume2/issue2/ fisheries/art-05.html

Kumakura N., Okuzawa K., Gen K., Kagawa H. 2003. Effects of gonadotropin-releasing hormone agonist and dopamine antagonist on hypothalamus-pituitarygonadal axis of pre-pubertal female red seabream ( $\mathrm{Pag}$ rus major). General and Comparative Endocrinology 131: 264-273.

Masson-Pévet, M., Gauer F., Schuster C., Guerrero H.Y. 2000. Photic regulation of $\mathrm{mt}_{1}$ melatonin receptors and 2-iodomelatonin binding in the rat and Siberian hamster. Biological Signals and Receptors 9: 188-196.

Peter R.E. 1968. Failure to detect an effect of pinealectomy in goldfish. General and Comparative Endocrinology 10: 443-449.

Peter R.E. 1970. Hypothalamic control of the thyroid gland activity and gonadal activity in the goldfish $\mathrm{Ca}$ rassius auratus. General and Comparative Endocrinology 14: 334-356.

Peter R.E., Trudeau V.L., Sloley B.D. 1991. Brain regulation of reproduction in teleosts. Bulletin of the Institute of Zoology, Academia Sinica, Monograph 16: 89-118.

Popek W. 1991. Rola szyszynki w rozwoju i dojrzewaniu gonad karpia (Cyprinus carpio L.). [The role of the pineal gland in development and maturation of carp (Cyprinus carpio L.) gonads.] Zeszyty Naukowe Akademii Rolniczej w Krakowie (157): 1-103. [In Polish.]

Popek W., Bieniarz K., Epler P. 1991. Role of the pineal gland in sexual cycle in common carp. Pp. 99-102. In: Surowiak J., Lewandowski M.H. (eds.) Chronobiology and chronomedicine. Verlag Peter Lang, Frankfurt.

Popek W., Breton B., Piotrowski W., Epler P., Bieniarz K. 1994. The role of the pineal gland in the control of a circadian pituitary-gonadotropin release rhythmicity in mature female carp (Cyprinus carpio L.). Neuroendocrinological Letters 16: 183-193.

Popek W., Epler P. 1999. Effects of intraventricular melatonin microinjections on hypothalamic catecholamine activity in carp females during a year. Electronic Journal of Polish Agricultural Universities, Fisheries 2 (2): http://www.ejpau.media.pl/volume2/issue2/fisheries/art-02.html
Popek W., Epler P., Kime D.E., Sokołowska-Mikołajczyk M. 1996. Melatonin does not affect steroidogenesis or maturation of carp oocytes in vitro during the prespawning period. Polish Archives of Hydrobiology 43: 379-385.

Popek W., Galas J., Epler P. 1997. The role of pineal gland in seasonal changes of blood estradiol level in immature and mature carp females. Archives of Polish Fisheries 5: 259-265.

Popek W., Łuszczek-Trojnar E., Drąg-Kozak E., Fortuna-Wrońska D., Epler P. 2005. Effect of the pineal gland and melatonin on dopamine release from perifused hypothalamus of mature female carp during spawning and winter regression. Acta Ichthyologica et Piscatoria 35: 65-71.

Popek W., Łuszczek-Trojnar E., Epler P. 2000. Effects of pineal gland and melatonin on maturation gonadotropin $(\mathrm{GtH} 2)$ secretion from perifused pituitary glands of mature carp during spawning. Electronic Journal of Polish Agricultural Universities, Fisheries 3 (1): http://www.ejpau.media.pl/volume3/issue 1/fisheries/art-01.html

Popek W., Węgrocka A., Drąg E., Epler P. 2002. Udział szyszynki w hormonalnej regulacji dojrzewania płciowego u samic karpia. [Effect of the pineal gland in hormonal regulation of sexual development in female carp.] Medycyna Weterynaryjna 58: 371-374. [In Polish.]

Schuster C., Gauer F., Malan A., Recio J., Pévet P., Masson-Pévet M. 2001. The circadian clock, light/ dark cycle and melatonin are differentially involved in the expression of daily and photoperiodic variations in mt1 melatonin receptors in the Siberian and Syrian hamsters. Neuroendocrinology 74: 55-68.

Senthilkumaran B., Joy K.P. 1995. Changes in hypothalamic catecholamines, dopamine- $\beta$-hydroxylase, and phenylethannolamine-N-methyltransferase in the catfish Heteropneustes fossilis in relation to season, raised photoperiod and temperature, ovariectomy, and estradiol-17 $\beta$ replacement. General and Comparative Endocrinology 97: 121-134.

Senthilkumaran B., Joy K.P. 1996. Effects of administration of some monoamine-synthesis blockers and precursors on ovariectomy-induced rise in plasma gonadotropin II in the catfish Heteropneustes fossilis. General and Comparative Endocrinology 101: 220-226.

Urasaki H. 1972. Effects of pinealectomy on gonadal development in the Japanese killifish (medaka) Oryzias latipes. Annotationes Zoologicae Japonenses 45: 10-15.

de Vlaming V.L. 1974. Environmental and endocrine control of teleost reproduction. Pp 13-83. In: Schreck C.B. (ed.) Control of sex in fishes. Virginia Polytechnic Institute and State University, Blacksburg, VA.

Yaron Z. 1995. Endocrine control of gametogenesis and spawning induction in the carp. Aquaculture 129: 49-73. 
Yu K.L., Peter R.E. 1992. Adrenergic and dopaminergic regulation of gonadotropin-releasing hormone release from goldfish preoptic-anterior hypothalamus and pituitary in vitro. General and Comparative Endocrinology 85: 138-146.

Zisapel N., Barnea E., Anis Y., Izhaki J., Reiter R.J., Haim A. 1998. Involvement of the pineal gland in daily scheduling of the golden spiny mouse. Life Science 63: 751-757.

Zisapel N., Egozi Y., Laudon M. 1985. Circadian variations in the inhibition of dopamine release from adult and newborn rat hypothalamus by melatonin. Neuroendocrinology 40: 102-108.

Zisapel N., Laudon M. 1983. Inhibition by melatonin of dopamine release from rat hypothalamus: regulation of calcium entry. Brain Research 272: 378-381.

Received: 21 December 2006

Accepted: 1 February 2007

Published electronically: 15 February 2007 